\title{
KETIKA MOHAMMED ARKOUN MEMBINCANG WAHYU
}

\author{
Mahrus eL-Mawa
}

P3M STAIN Cirebon. Jl. Perjuangan By Pass Sunyaragi Cirebon 45132 Telp. (0231) 481264

\begin{abstract}
Expressing of somebody's thought is like open a window of ideas world on a period. Terminology of "wahyu" in Qur'anic studies, very often only concentrated to its subject in a past. Hence, impress that researchers less express "wahyu" in modern perspective of science, such as linguistics, anthropology, and so on. Mohammed Arkoun is one among recent thinker of moslem trying to discussion about "wahyu". In context of Islamic thought, Arkoun's contribution enough mean to open the door of discourse on recent Islamic science. In this article can be known that how Arkoun in reading of "wahyu" has a new perpective.
\end{abstract}

Key words: wahyu, 'ulum al-Qur'an, al-Qur'an

\section{Pendahuluan}

Mohammed Arkoun dilahirkan pada tanggal 1 Februari 1928 di Aljazair atau tepatnya di Taorirt-Mimon, Kabilia sebelah timur Aljir (Algeria), suatu daerah pegunungan yang dihuni oleh masyarakat berpenduduk Berber (Meuleman, 1994: 1; Arkoun, 1996: 208).

Ulul Albab, Vol. 8 No. 2, 2007 
Berber (al-barbar) adalah penduduk Afrika bagian utara, dari Libya hingga Samudera Atlantik. Mereka berbicara dengan berbagai logat nonArab (lahjah a'jamiyyah) sebelum terarabkan, atau hingga kini juga masih ada yang menggunakan bahasa Berber itu. Asal usul mereka berasal dari beberapa kelompok yang telah menetap di sana, semenjak pra-Masehi, antara lain yang terkenal adalah daerah Numidia dan Mauritania. Kehidupan mereka bercampur-baur dengan orang-orang Finicia (fainiqiyyun) dan Yunani. Sewaktu imperium Romawi menguasainya, mereka tidak menganut secara utuh hukum Romawi dan agamanya, agama Kristen. Sebagian besar diantara mereka masuk Islam bersama Uqbah ibn Nafi ( $w$. 63/683) dan mereka juga ikut bersama tentara Arab dalam berbagai penaklukannya di Spanyol, di antara salah satu panglimanya adalah Tariq ibn Ziyad (w. 102/720) (Ajil, 1984: 472). Selanjutnya, mereka mengikuti kaum Khawarij ketika memberontak terhadap Bani Abbasiah. Akhirnya, mereka terbagi ke dalam beberapa kerajaan dan dinasti, antara lain Dinasti Aglabiyyah, Murabitun, dan Muwahidun, yang pada penghujung abad XIII kekuasaan mereka hancur. Bagi mereka yang berada di perkotaan, berbaur dengan orang Arab dan yang lainnya, berdiam di pegunungan Auras (sebelah tenggara), pegunungan Atlas (yang terbentang antara Maroko, Aljazair dan Tunisia), pegunungan Rif (sebelah utara Maroko) dan di Kabilia - suatu tempat dimana Arkoun dilahirkan-. Sebagian mereka, hingga kini masih tetap mempertahankan tradisi dan bahasa Berbernya itu (Sa'ad, 1995: 17).

Kabilia (al-qaba'il) adalah suatu daerah di Aljazair, terdiri dari Kabilia besar — sekitar satu juta hektar — dan Kabilia kecil. Kehidupan masyarakatnya berasal dari hasil pertanian (buah tin dan zaitun), menggembala ternak, dan kerajinan tangan. Sedangkan secara sosio-kultural, di Kabilia tidak dikenal tulisan; yang ada hanyalah bahasa lisan (Sa'ad. 1995: 20).

Aljazair/al-jaza'iriah (al-jumhuriyyah —ad-dimuqratiyyah asy-sya'biyyah) adalah sebuah negara Arab yang berada di Afrika bagian utara, dengan Kota Aljir (al-jaza'ir) sebagai ibu kotanya. Secara historis, pada tahun 682 M. telah menjadi bagian Arab - yakni Bani Umayah_- bersamaan dengan 
penyebaran Islam oleh Uqbah ibn Nafi, selanjutnya dikuasai oleh Dinasti Fatimiyyah. Namun pada tahun 1518, berpindahberada dibawah kekuasaan Dinasti Usmaniyyah. Kemudian mulai tahun 1830, Aljazair ditundukkan dan dikuasai oleh Perancis sampai dengan 1962. Karena, pada tanggal 3 Juli 1962 merupakan hari kemerdekaan bagi rakyat Perancis. Jadi secara politis, pada saat Arkoun lahir dan dibesarkan, Aljazair berada di bawah tangan kolonial Perancis.

Menurut Hodgson — seperti dikutip Suadi Sa'ad— saat kolonialisme itu, orang Muslim akan diberi hak-hak istimewa sebagaimana orang-orang Perancis, hanya jika bersedia menerima hukum kekeluargaan mereka. Artinya, orang Muslim bersedia meninggalkan hukum kekeluargaannya sebagai muslim yang berdasarkan syariat. Namun dalam kenyataannya, orang Muslim, bahkan mereka yang cukup terdidik di sekolah-sekolah Perancis, jarang memilih menjadi warga Perancis, sekalipun secara kultural/ budaya telah terperanciskan. Pada situasi dan kondisi demikian, kita bisa melihat lingkungan dan kehidupan Arkoun yang lebih banyak terdidik ala pendidikan Perancis (Sa'ad, 1995: 21).

Dari paparan singkat di atas, sebagai orang yang dibesarkan dalam tradisi dan budaya Berber yang sarat dengan nuansa keagamaan; Kabilia yang belum mengenal budaya tulisan; Aljazair yang banyak menggunakan bahasa Arab; dan Perancis —sebagai kolonialis_ yang mewajibkan menggunakan bahasa Perancis dalam pendidikan dan urusan administratif, menjadikan Arkoun lebih menggeluti pada persoalan bahasa dan sastra. Jadi, boleh dikatakan bahwa Arkoun hidup dan bergaul dengan tiga bahasa tersebut; bahasa Kabilia sebagai salah satu bahasa Berber yang dikenal sebagai bahasa lisan, bukan yang tertulis; bahasa Arab yang tertulis sebagai bahasa keagamaan dari seorang Muslim di Aljazair; dan bahasa Perancis sebagai bahasa non-keagamaan yang digunakan dalam pendidikan dan untuk dapat lebih mengenal tradisi dan budaya Barat (Meuleman, 1993: 94). Karena itu pula - barangkali_, sehingga Arkoun menganggap bahwa setiapbahasa mempunyai latar belakang dan nilai kelebihan tersendiri, tidak semata-mata sebagaialat teknis dan sarana komunikasi. Seperti dicontohkan

Ulul Albab, Vol. 8 No. 2, 2007 
Arkoun bahwa tidak semua bahasa Perancis dapat diterjemahkan dalam bahasa Arab atau juga sebaliknya, bahasa Arab (bahasa al-Qur'an) tidak dapat diterjemahkan dengan bahasa yang lainnya. Seperti, kosa kata alwahy dalam bahasa Arab yang digunakan dalam al-Qur'an tidak dapat diterjemahkan atau dimaksudkan 'sama' dalam bahasa manusia yang tidak sakral — karena, ternyata tidak hanya mempunyai satu makna (Arkoun, 1992: 79).

Satu hal yang patut untuk menjadi catatan, bahwa Arkoun selama ini selalu menggunakan bahasa Perancis sebagai bahasa tulisnya, bukan bahasa Kabilia sebagai bahasa ibunya atau bahasa Arab sebagai bahasa Nasional Aljazair. Hal ini, bukan karena Arkoun telah terperanciskan atau tidak pandai dalam bahasa Arab, tetapi lebih dilatarbelakangi oleh telah banyaknya menemukan 'masalah' ketika mengungkapkannya dalam bahasa Arab. Sebagaimana diungkapkan oleh Arkoun (dalam Meuleman, 1993. 3) sendiri, dalam sebuah artikelnya;

“...Karena berbagai perkembangan yang lebih menentukan... sejak tahun '50-an, tidak ada lagi kemungkinan dipahami, dalam bahasa Arab maupun suatu bahasa Islam, semua rujukan kepada epistemologi kritis, kritik wacana, sejarah dekonstruktif... yang secara keseluruhan tetap gelap bagi para intelektual satu-bahasa. Fenomena sosio-kultural ini membentang di mana-mana sehingga membebani penggunanan bahasa Arab satu-satunya, misalnya."

Namun untuk beberapa tahun terakhir ini, Arkoun juga menulis dalam bahasa Arab, untuk mempergiat pertukaran intelektual, katanya (Arkoun, 1997: 8). Dengan 'keseriusan'-nya dalam bidang bahasa seperti tersebut di atas, Arkoun juga menyebutkan bahwa Linguistik —maksudnya, linguistik modern—adalah kunci untuk memasuki al-Qur'an (Arkoun, 1990: 86).

\section{Tentang Pendidikan, Karir dan Karya Arkoun}

Sebagaimana 'hukum-alam' suatu kolonialisme, semua sektor yang menguntungkan berada dalam genggamannya, termasuk juga bidang 
pendidikan. Oleh karenanya ketika Arkoun akan mencari ilmu secara formal, mau tidak mau harus memasuki lembaga pendidikan ala Perancis, yang nota-bene Barat sentris.

Dalam perspektif pendidikan formal-akademik-modern, Arkoun telah merampungkannya sampai pada tingkat yang paling tinggi. Pendidikan dasar, ia selesaikan di desa kelahirannya. Kemudian melanjutkan studinya pada salah satu SMU di kota pelabuhan Oran yang jauh dari daerah Kabilia. Pada saat itulah, ia mendalami bahasa Arab dan setamatnya dari SMU (1950-1954) ia belajar bahasa dan sastra Arab di Universitas Aljir, sembari mengajar bahasa Arab pada salah satu SMU di al-Harrach, Aljazair. Selanjutnya, di tengah perang pembebasan Aljazair dari Perancis (antara tahun 1954-1962) Arkoun mendaftarkan diri sebagai mahasiswa di Paris. Bidang yang ia geluti tetap tidak berubah, yakni bahasa dan sastra Arab, bahkan saat 'menggondol' gelar Doktornya pada tahun 1969 di Universitas Sorbonne Paris, ia tetap konsisten pada bidangnya itu, yakni sebagai Doktor bidang Sastra (Meuleman, 1993: 1-2).

Semenjak hijrah ke Paris — saat menjadi mahasiswa—, sejakitu pulalah Arkoun mulai menetap di sana. Adapun tentang karir, Arkoun termasuk orang yang cepat meningkat dengan pesat. Pertama kali sebagai agrege (pengajar menengah) bahasa dan kesusasteraan Arab di Paris. Kemudian tahun 1956-1959, ia menjadi guru SMU (Lycee) di Starsbourg, sembari dimintamemberi kuliah di Fakultas Sastra di Universitas Starsbourg. Antara tahun 1959-1969, ia menjadi profesor madya di Sorbonne dan pada tahun 1961 diangkat menjadi dosen pada Universitas Sorbonne di Paris. Setelah itu pada tahun 1969-1972, ia berpindah mengajar di Universitas Lyon II. Selanjutnya, kembali lagi ke Paris dan menjabat Profesor bahasa Arab dan peradaban Islam di Universitas Paris VIII (1972-1977) (Tamara, 1989: 45).

Selain menjadi pengajar di Paris dan dosen tamu (visiting professor) atau penceramah ke luar Perancis, seperti pada University of California in Los Angeles, Lembaga Kepausan untuk Studi Arab dan Islam di Roma, Universitas Katolik Louvain-la-Neuve di Belgia, Princeton University dan Temple University di Philadelphia, Universitas (kota praja) Amsterdam,

Ulul Albab, Vol. 8 No. 2, 2007 
Tunis, Damaskus, Harvard, Columbia, Beirut, Tehran, dan lain-lain. termasuk juga Indonesia. Karir lainnya, Arkoun juga pernah memangku beberapa jabatan terhormat. Misalnya, Direktur ilmiah dari majalah studi Islam terkenal Arabica, anggota panitia nasional Prancis untuk etika dalam ilmu pengetahuan kehidupan dan kedokteran, angota majlis nasional untuk AIDS, Direktur institut kajian dunia Arab dan Islam di Universitas Sorbonne Nouvelle (Paris III), dan terakhir menjabat Profesor sejarah pemikiran Islam di Universitas yang sama (Tamara, 1989).

Dari pendidikan yang digelutinya dan pengalaman yang menyertainya -seperti deskripsi singkat di atas-, dalam menuliskan berbagai pokok pikirannya, Arkoun lebih bertolak dari usaha dasarnya untuk menggabungkan hasil mutakhir berbagai ilmu pengetahuan Barat dengan pemikiran Islam, guna membebaskan pemikiran Islam tersebut dari kekakuan dan ketertutupannya atau dengan lain kata, membukanya pada masalah yang dihadapi manusia modern (Meuleman, 1993). Premis tersebut bisa kita lihat dalam beberapa karyanya yang telah tersebar luas, termasuk yang telah diterjemahkan dalam bahasa Arab, Inggris dan Indonesia.

Beberapa karya tersebut, sebagian diterbitkan pada majalah terkemuka sepertiMaghreb-Mashreq (Paris), Islamo-Christiania (Vavikan), Diogene (Paris), Arabica (Leiden/Paris), dan Studia Islamica (Paris). Sedangkan sebagian karyanya yang telah menjadi sebuah buku tersendiri adalah beberapa kumpulan darimajalah tersebut. Sebagai contoh misalnya; Essais surla pensee islamique (Esei-esei tentang Pemikiran Islam), Paris: Miasonneuve et Larose, 1973; Lectures du Coran (Pembacaan-Pembacaan Quran), Paris: Maisonneuve et Larose, 1982; dan Pour une critique de la raison islamique (Demi Kritik Nalar Islami/Nalar Islami dan Nalar Modern: Sebuah Tantangan dan Jalan Baru —seperti terjemahan INIS, Jakarta-), Paris; Maisonneuve et Larose, 1984.

Buku-buku Arkoun yang terpenting, antara lain; Traite d'ethique (traduction francaise avec introduction et notes $d u$ Tahdhib al-Akhlaq de Miskawaih), yakni Tulisan tentang Etika (terjemahan Perancis dengan Pengantar dan Catatan dari Tahzibal-Akhlaqkarya Miskawaih), Damaskus: 
1969; Contribution a l'etude de l'humanisme arabe au IVIX siecle: Miskawaih philosophe et historien, yakni Sumbangan pada Pembahasan Humanisme Arab pada Abad IV/X: Miskawaih sebagai Filsuf dan Sejarahwan, Paris: J. Vrin, 1970; La Pensee Arabe, yakni Pemikiran Arab, Paris: P.U.F., 1975; dan Ouvertures sur l'Islam, yakni Catatan-catatan Pengantar untuk mengetahui Islam, Paris: Grancher, 1989 (Meuleman, 1993).

Beberapa buku lainnya, yang sempat tercatat adalah Aspect de la pensee musulmane classique (Aspek-Aspek Pemikiran Islam Klasik), Paris: IPN, 1963; Deux epitres de Miskawaih (Dua Surat Miskawaih), Edisi kritis, Damaskus: 1963; Discourse coranique et pensee scientifique (Wacana Al-Qur'an dan Pemikiran Ilmiah), Paris: Sinbad; L'Islam, hier, demain (Islam, Kemarin dan Esok Hari), karya bersama Louis Gardet, Buchet-Chastel, Paris: 1982, LIslam religion et societe (Islam, Agama dan Masyarakat), karya bersama M. Arosic dan M. Bornmans, Paris: 1982, ed. Cerf (Sa'ad. 1995: 28).

Selain tulisan Arkoun seperti tersebut di atas, masih terdapat puluhan lagi yang tersebar di jurnal ilmiah ataupun dalam makalah forum-forum lain, khususnya yang berupa terjemahan dari bahasa Perancis. Seperti, dalam bahasa Inggris; "The Death Penalty and Torture in Islamic Thought", Concilium, London: 1978/10; "Is Islam Threatened by Christianity?", Concilium, London: 1994/3; "The Notion of Revelation: From Ahl al-Kitab to the Societes of the book", Die Welt des Islams, Paris: 1988/XXVIII; Adapun tulisan Arkoun sendiri yang berbahasa Inggris adalah Rethinking Islam Today, Washington: Center for Contemporary Arab Studies, 1987.

Dari karya-karya Arkoun di atas, yang sempat diterjemahkan dalam bahasa Arab dan Indonesia, antara lain; Al-Fikr al-Islami: Qira'at 'Ilmiyyah, 1987; Al-Islam: al-Akhlaq wa as-Siyasah, 1990; Tarikhiyyat al-Fikr al-'Arabi al-Islami, 1986, ketiganya terbit di Beirut: Markaz al-Inma' al-Qaumi; AlFikr al-Islam: an-Naqd wa Ijtihad, 1992; Min Faisal at-tariqah ila Fasl al-Maqal, aina huwa al-Fikr al-Islami al-Mu'assir?, 1993; Al-Islam, Auruba, al-Garb: Rahanah al-Ma'na wa Iradat al-Haimanah, 1995, ketiganya terbit di Beirut: Dar al-Saqi dan keenamnya itu dialih-bahasakan oleh Hasyim Salih; dan Al-Islam: Asalah wa Mumarasah, oleh Khalil Ahmad, 1986.

Ulul Albab, Vol. 8 No. 2, 2007 
Sedangkan yang dialih-bahasakan ke Indonesia, antara lain; Nalar Islami dan Nalar Modem: Berbagai Tantangan dan Jalan Baru, oleh Rahayu S. Hidayat, 1994; Berbagai Pembacaan Quran, oleh Machasin, 1997; "Gagasan Tentang Wahyu: Dari Ahl al-Kitab sampai Masyarakat Kitab", dalam bagian buku Studi Islam di Perancis, oleh Lilian D.T., 1993. Ketiga karya Arkoun tersebut terbit di Jakarta: INIS. Islam Kemarin dan Hari Esøk, Penterj. Ahsin Muhammad, Bandung: Pustaka, 1997; Pemikiran Arab dan Rethinking Islam, keduanya dialih-bahasakan oleh Yudian W. Asmin dengan dibantu Lathiful Khuluq untuk Rethinking Islam, menerjemahkan dari bahasa Inggris, Yogyakarta: Pustaka Pelajar, 1996. Tulisan Arkoun lain yang termaktub dalam Jurnal Ilmiah, antara lain; "Menuju Pendekatan Baru Islam" wawancara bersama Hamid Basyaib, II (1990), "Pemikiran Tentang Wahyu: Dari Ahl al-Kitabsampai Masyarakat Kitab", oleh Nurul Agustina, II/IV (1993); "Metode Krtik Akal Islam", oleh Ulil Abshar Abdallah, Vdan VIN (1994), ketiganya diterbitkan oleh Jumal Ulumul Qur'an: Jakarta; "Kearah Islamologi Terapan", penterj. Syamsul Anwar dalam Jumal AlJami'ah IAIN Sunan Kalijaga Yogyakarta, LIII/Th.1993; dan "Dialog Antaragama di Era Postmodernisme”, penterj. Ruslani dalam Suara Muhammadiyyah, XIX/LXXXII (1997), edisi 1-15 Oktober.

Dari sekian banyaknya Arkoun menulis, menurutNasir Tamara, cukup nampak sekali bahwa Arkoun sangat memperhatikan berbagai persoalan dalam Islam, khususnya pada soal pemikiran Islam, masalah kemasyarakatan, pemahaman tentang Kitab suci, pengertian etika, dan kaitannya antara Islam dan Modernitas (Tamara, 1989: 46). Oleh karena itu tidaklah mengherankan, bila Meuleman menyatakan bahwa Arkoun termasuk salah seorang pemikir muslim mutakhir yang preduktif (Meuleman, 1993: 95).

\section{Pikiran Arkoun tentang Wahyu}

Sesuatu 'yang tak terpikir' merupakan salah satu gagasan yang dikembangkan Arkoun, yang cukup mampu membukakan mata nalar kita, baik untuk pengkajian Islam lebih lanjut ataupun sekedar memperhatikan 
dalam studi urainya. Kemudian, yang tak kalah menariknya juga adalah gagasan-gagasan Arkoun tentang sesuatu 'yang tak dipikir'. Dari dua gagasan ini, sepertinya Arkoun mencoba memberikan pemaknaan atas fenomena wahyu-ilahi, dengan sedikit-banyak melebihi atas kajian yang telah ada.

\section{Wahyu dan Al-Qur'an: 'Pembacaan' Baru}

"Tidak semestinya bagi seorang manusia, bahwa Allah akan berbicara kepadanya kecuali dengan wahyu, atau dari balik tabir, atau mengutus seorang utusan, lalu ia diberi wahyu apa yang Ia kehendaki dengan izinNya. Sungguh, Ia Mahaunggi, Mahabijaksana. Dan demikianlah, Kami sampaikan kepadamu wahyu, atas perintah Kami, yang (sebelumnya) tak kau ketahui Kitab itu dan iman itu apa. Tetapi Kami jadikan itu (al-Qur'an) Cahaya; Kami bimbing siapa yang Kami kehendaki dari hamba-hamba Kami; dan engkau pasti membimibng (manusia) ke jalan yang lurus" (QS. asy-Syura: $51-52)$.

"Ha-Mim. Demi Kitab yang sudah jelas. Kami menjadikannya sebuah al-Qur'an dalam bahasa Arab, supaya kamu mengerti. Dan sungguh dalam induk Kitab pada pihak Kami, sangat tinggi, penuh hikmah. Ataukah akan Kami cabut peringatan dari kamu karena kamu golongan orang yg melanggar batas?" (QS. az-Zukhruf: 1-5).

Kedua surah dan ketujuh ayat dari al-Qur'an di atas, merupakan langkah awal yang diambil Arkoun saat mengkaji tentang wahyu-ilahi, lebih khusus pada QS. asy-Syura: 51-52. Pada ayat tersebut, sesungguhnya Arkoun tidak 'membaca' secara panjang lebar, hanya disebutkan bagaimana perincian al-Qur'an atas mekanisme wahyu itu (Arkoun, 1990: 78). Adapun secara definitif dan singkat telah dipaparkan sebelumnya. Beberapa ayat lain yang di-'baca' Arkoun antara lain, QS. al-Jin: 1, (Arkoun, 1987: 187) QS. asy-Syura: 7 dan 13 (Arkoun, 1997: 111).

Pada dasarnya, dari ayat-ayat tersebut memang secara lafzi dan tekstual tidak diberikan makna atau tafsirannya oleh Arkoun. Sehingga dalam

Ulul Albab, Vol. 8 No. 2, 2007 
penafsirannya itu, terkesan tidak berbeda dengan para pemikir lain yang bukan mufasir. Sebagaimana, 'kebiasaan' Arkoun ketika mengambil atau mengutip salah satu pendapat dari para intelektual, pemikir 'kenamaan' yang dianggap relevan dengan apa yang akan ditulisnya. Karena, metode pembacaan al-Qur'an Arkoun —sementara ini-tidak dalam bentuk ayat per-ayat (tahlili), tapi lebih dekat pada 'tematik' dan surat per-surat, misalnya pembacaanya terhadap QS. al-Fatihah dan al-Kahf, atau yang tematik itu tentang Haji. Lebih dari itu, tiga ayat terakhir di atas yang di dalamnya ada lafal derivasi al-wahy, Arkoun tidak menjelaskan tentang wahyu itu sendiri, tapi membicarakan tema yang lain. Seperti QS. al-Jin: 1, Arkoun memaparkannya berkaitan dengan Keajaiban dalam al-Qur'an, kemudian QS. asy-Syura: 7, dipaparkannya berkaitan dengan Agama dan Masyarakat berdasarkan Islam, dan pada QS. asy-Syura: 13, berkaitan dengan bagaimana memperibncangkan Islam dewasa ini. Namun demikian, dalam beberapa tulisannya Arkoun memaparkan tentang wahyu, baik perspektif al-Qur'an ataupun dalam perspektif yang lainnya, seperti akan dibahas di sini.

Bilamana kita melihat kembali pada pembedaan tingkatan wahyu, khususnya tingkat yang ketiga, yakni wahyu yang telah tertulis dalam Mushaf, menjadikan penulis melihat lebih jauh 'pembacaan' Arkoun tentang al-Qur'an atau al-Mushaf al-'Usmani. Atau dalam pernyataan lain, bahwa membicarakan wahyu bersama Arkoun, sesungguhnya tidak dapat dilepaskan dari 'pembacaan' Arkoun sendiri tentang al-Qur'an. Maksudnya, al-Qur'an yang telah menjadi al-Mushaf (korpus resmi tertutup). Barangkali (untuk hal ini) karena gambaran Arkoun sendiri, seperti pada diagram yang dibuatnya itu. Oleh karenanya sampai pada batas ini, penting untuk diperhatikan terlebih dahulu tentang 'bacaan' Arkoun tentang al-Qur'an/ Mushaf.

Bentuk participle atau fil al-madi dari kata al-Qur'an adalah qara'a. Akar katanya adalah q-r-', mengandung pengertian (arti) lebih dari sekedar tilawah (membaca). Disebut demikian, karena tidak mensyaratkan adanya sebuah teks tertulis ketika pertama kali mengucapkan wahyu yang diterima 
Muhammad. Hal ini relevan dengan bunyi ayat 16,17 dan 18 pada QS, alQiyamah;

"Janganlah gerakkan lidahmu untuk (al-Qur'an) dengan maksud ingin cepat-cepat. Kami-lah yang akan mengumpulkannya dan membacakannya: Bila Kami sudah membacakannya, maka ikutilah bacaannya".

Dalam sejumlah ayat, kata Arkoun, penekanannya terdapat pada kebutuhan Nabi untuk menyesuaikan bacaan ayat-ayat, sesuai dengan tilawah sebagaimana yang nabi dengar sendiri. Beberapa Orientalis-filologis berpendapat bahwa kata al-Qur'an, memiliki asal-usul Syiria atau Hebrew, namun pengamatan mereka itu -lanjut Arkoun - tidak memodifikasi pengertian (makna) yang dituntut oleh konteks Qur'anik sendiri.

Jadi ide dasar al-Qur'an, menurut Arkoun adalah ide tilawah yang sesuai dengan suatu khitab (wacana lisan) yang didengar (masmu'), bukan dibaca (maqru') (Arkoun, 1997. 45). Sampai di sini, Arkoun 'membaca' dan membedakan antara al-qur'an dan al-wahy secara etimologis (lafzi). Sehingga yang perlu diperhatikan dalam 'pembacaan' Arkoun tersebut, bahwa wacana al-Qur'an (khitab qur'ani) adalah al-wahy itu sendiri tentu saja, ini agak berbeda dengan tanzil-. Bahkan dikatakan Arkoun sendiri, bahwa ia lebih mengutamakan pengggunaan wacana al-Qur'an dibanding teks al-Qur'an, pada fase awal penyampaian ayat-ayat al-Qur'an di zaman Nabi Muhammad, hal ini bukan semata-mata persoalan linguissemiotis, tapi juga antropologis (Arkoun, 1997: 205).

Sedangkan al-Qur'an secara definitif (istilahi), Arkoun tidak bersedia untuk lebih jauh memaparkannya lagi, dengan asumsi 'khawatir' akan menjadi bahan ketawaan, karena telah banyaknya definisi. Disamping pula, menurut hemat penulis, karena tidak mau selalu 'sama' sebagaimana layaknya para pemikir, sebelumnya.

Terlepas dari asumsi tersebut, dalam bagian tulisannya tentang "Menuju Pemersatuan Kembali Kesadaran Islam", ia menjelaskan bahwa al-Qur'an

Ulul Albab, Vol. 8 No. 2, 2007 
adalah sejumlah makna potensial yang diusulkan kepada segala manusia. Selanjutnya, dikatakan pula bahwa al-Qur'an adalah sebuah teks terbuka, yang tak satupun penafsiran dapat menutupnya secara tetap dan 'ortodoks'. Hal ini sesuai dengan paparan Arkoun dalam La Pensee Arabe. Al-Qur'an adalah sebuah korpus yang selesai, artinya benar-benar terbatas dalam jumlah ujaran yang membentuknya, sudah selesai baik dalam bentuk pengungkapannya maupun dalam bentuk isinya. Setelah korpus itu selesai, juga terbuka, dengan kata lain, teks al-Qur'an mengatakan sesuatu, melakukan suatu komunikasi, dan 'membuat berpikir', tidak peduli bagaimanapun keadaan wacana yang di dalamnya pembacaan itu terjadi. Dan maksudnya ujaran-ujaran, adalah kenyataan bahwa al-Qur'an telah dan masih merupakan sebuah 'perkataan' sebelum menjadi teks tertulis (Arkoun, 1997).

Pada sisi lain, Arkoun memandang bahwa al-Qur'an yang dianggap sebagai sebuah Kitab suci yang dijadikan pedoman hidup (way of life) bagi umat Islam, yang telah ditafsirkan oleh banyak ulama dan kelompok (mazhab), hanyalah merupakan suatu "alat, mediator, zari ' ah" saja untuk membangun teks-teks lain yang dapat memenuhi kebutuhan dan selera suatu masa tertentu setelah masa turunnya al-Qur'an. Jadi, seluruh tafsirtafsir yang ada itu, memang sudah ada 'dengan sendirinya' serta 'untuk dirinya' sendiri. Semuanya lebih merupakan sebagai karya intelektual serta produk budaya yang terikat dengan konteks kultural yang melatarinya, dengan lingkungan sosial atau aliran teologi yang menjadi "payungnya", daripada dengan konteks al-Qur'an itu sendiri (Arkoun, 1994: 157). Maka adalah relevan, ketika dalam tulisan "Persoalan Apakah al-Qur'an BenarBenar Berasal dari Tuhan?", Arkoun memaparkannya tidak menjawab 'ya' atau 'tidak'. Karena tujuan dari Arkoun pada tulisan tersebut hanyalah 'mengingatkan' akan tempat-tempat yang strategis dari suatu perenungan pembaru mengenai makna agama. Dan di dalam paparannya itu, justru pertanyaan-pertanyaan kritis, disamping Arkoun menjelaskannya dengan bantuan historis, antropologis dan linguistis, yang berbeda dengan biasanya yang hanya dalam batas teologis. Dari pendekatan ini, menurut Meuleman, 
Arkoun menolak penditian bahwa al-Qur'an sebagai hal yang setba transenden, tanpa hubungan apa pun dengan sejarah manusia yang konkrit dan Arkoun juga menolak pendirian yang mereduksi al-Qur'an hanya pada gejala historis semata.

Melihat semua itu, Arkoun mengajak pada kita — sebagai pembacauntuk 'membaca' al-Qur'an menurut aturan-aturan sebagai berikut:

1) Mengangkat makna dari apa yang disebut dengan sacra doctrina (ajaran suci) dalam Islam dengan menundukkan teks al-Qur'an dan semua yang dalam sejarah pemikiran Islam telah berusaha untuk menjelaskannya.

2) Menetapkan suatu kriteriologi yang didalamnya akan dianalisis motifmotif yang dapat dikemukakan oleh kecerdasan masa kini, baik untuk menolak maupun mempertahankan konsep-konsep yang dipelajari (Arkoun, 1993: 50).

Sesungguhnya aturan-aturan tersebut merupakan suatu metode yang dapat diterapkan pada semua teks doktrinal besar. Oleh karena itu, untuk 'pembacaan'-nya, kata Arkoun, mau tidak mau mesti mencakup tiga kecenderungan:

1) Linguistis yang memungkinkan kita untuk menemukan keteraturan dasar di bawah ketakteraturan yang tampak.

2) Antropologis, yakni mengenali bahasanya dalam al-Qur'an bahasanya yang bersusunan mitis.

3) Historis yang di dalamnya akan ditetapkan jangkauan dan batas-batas tafsir logiko-leksikografis dan tafsir-tafsir imajinatif yang sampai hari ini dicoba oleh kaum muslimin.

Selain itu, untuk 'membaca kembali' al-Qur'an, menurut Arkoun tidak boleh tidak untuk melupakan kondisi yang terjadi pada islamologi klasik (Arkoun, 1993: 63). Oleh karena itu, tawarannya tentang islamologi terapan

Ulul Albab, Vol. 8 No. 2, 2007 
-yang mengkaji Islam cenderung menyulih tradisi apologetik dan polemik yang panjang, sebagai kegiatan ilmiah intern, dan menyumbang kepada antropologi keagamaan, sebagai kajian ilmiah yang solider dengan seluruh pemikiran kontemporer (keduanya saling melengkapi)_-, adalah juga merupakan suatu keharusan bagi Arkoun untuk melakukan hal itu (bilamana akan 'membaca kembali' al-Qur'an). Maksudnya, bukanlah menambah suatu pembacaan pada segala pembacaan yang telah ditimbulkan oleh Kitab yang diwahyukan. Katakanlah, menurut Arkoun, kita hanya hendak memunculkan di dalam pemikiran islami berbagai pertanyaan yang sejak lama lazim diajukan dalam pemikiran Kristen. Dengan begitu, kata Arkoun, al-Qur'an diuji melalui kritik kesejarahan, perbandingan, analisis kebahasaan yang dekonstruktif, renungan filsafati mengenai penghasilan, pembesaran, metamorfosa dan kehancuran makna.

Dari deskripsi di atas itu, nampaknya Arkoun berusaha agar tetap memperimbangkan wahyu sebagai sebuah gejala kultural, historis, semiotis (termasuk linguistis) dan antropologis (Arkoun, 1996: 21).

Berkaitan dengan pembacaannya terhadap al-Qur'an, ia juga menawarkan untuk menelusuri kembali segala bidang untuk menyusun suatu teo-antropo-logi wahyu yang harus dipahami sebagai suatu upaya gabungan, diperluas, dan diperkaya, menuju emansipasi kondisi manusia. Barangkali, hal itu yang dimaksud Meuleman bahwa tesis utama Arkoun adalah kajian teologis dan antropologis, yang masing-masing menyangkut Tuhan dan manusia, keduanya tak dapat dipisahkan. Seperti misalnya, Arkoun sering mempersoalkan status khas al-Qur'an sebagai kitab wahyu ilahi, dan perbedaan antara Kalam Allah dengan pembicaraan, penulisan, dan pemahaman manusia mengenai Kalam Allah.

Dari pelbagai konsekwensi kajian wahyu seperti tersebut di atas, maka selanjutnya perlu dibahas beberapa hal berkaitan dengan fenomena kajian Arkoun tentang wahyu yang ditekankan. Seperti, kajian kritisnya atas wahyu dari para pemikir sebelumnya atau wahyu dalam pikiran Islam yang telah menjadi fakta budaya. 


\section{a. Wahyu dalam Al-Qur'an: Sebuah Problem Linguistik}

Sebelum Arkoun membahas lebih jauh lewat perspektifnya sendiri, ia telah mengambil benang merah "Wahyu dalam Al-Qur'an" yang selama ini dikaji kaum 'ortodoks' dan tradisional (menggunakan istilah Arkoun). Hal semacam ini, menurut Arkoun, seperti yang hingga kini dipakai dalam semua ilmu keislaman (termasuk 'Ulum al-Qur'an) dan kitab tafsir. Secara ringkas, dirangkum dalam proposisi berikut ini:

1) Allah telah mengkomunikasikan kehendak-Nya kepada umat manusia melalui para Nabi, sesuai dengan bahasa manusia, agar dapat dipahami. Tetapi, Allah menyampaikan kalimat-kalimat-Nya itu dalam sintaksis, retorika, dan kosa-kata-Nya sendiri. Karena, tugas para Nabi hanyalah mengucapkan wacana yang dinyatakan-Nya sebagai bagian dari KalamNya yang tidak terbatas dan abadi — berbeda dengan kaum Mu'tazilah, yang menyatakan Kalam Allah itu diciptakan-.

2) Sunnah menyatakan dengan tegas bahwa Malaikat Jibril sebagai instrumen perantara antara Allah dan Nabi Muhammad.

3) Wahyu yang termaktub dalam Al-Qur'an dan disampaikan melalui Muhammad adalahyang terakhirdan ia melengkapi wahyu-wahyu yang mendahuluinya, yaitu diberikan kepada Nabi Musa yang termaktub dalam Taurat dan kepada Yesus (Nabi Isa al-Masih) yang termaktub dalam Injil, serta Kitab Zabur-nya Nabi Daud.

4) Wahyu yang dimanifestasikan dalam Al-Qur'an telah lengkap untuk semua kebutuhan kaum mukminin (dan secara potensial, seluruh umat manusia), tetapi tidak lengkap mewakili seluruh firman Allah yang tersimpan dalam umm al-kitab, kitab syurga/langit dan lauh mahfuz, daftar yang tersimpan.

5) Anggitan kitab langit yang disajikan begitu tegas dalam Al-Qur'an merupakan salah satu lambang kuno dan imaginaire (khayalan) keagamaan yang lazim dalam masyarakat Timur-Tengah kuno.

Ulul Albab, Vol. 8 No. 2, 2007 
6) Pengumpulan al-Qur'an menjadi sebuah bentuk fisik, yakni satu buku yang nyata dan yang dipakai secara umum (biasanya disebut dengan kitab, atau sering juga dengan al-mushaff, seluruhnya dipengaruhi oleh prosedur manusia yang tidak sempurna (misalnya, penyampaian secara lisan; penggunaan bentuk gambar yang tidak sempurna; kedudukan Sahabat Nabi [sahabah]; dan bacaan yang tak dilaporkan), tidaklah menjadi halangan untuk menjabarkan teori kalam Allah yang tidak diciptakan, wahyu yang diberikan secara lengkap dalam al-Qur'an, dan adanya jalan langsung yang autentik bagi manusia menuju kalam ilahi yang transandental ini (Lilian, 1993).

Proposisi ini, lanjut Arkoun, menyiratkan koeksistensi dua peringkat wahyu yang secara jelas terungkap dengan baik dalam pikiran orang-orang beriman, tetapi mengalami perbedaan secara intelektual dan praktis. Pertama, peringkat firman Allah yang dikaitkan dengan kitab langit, yang menjamin autentisitas dan transendensi kitab yang terwujud (Mushaf) adalah termasuk artikulasi secara intelektual. Kedua, peringkat literatur dan kesusasteraan Islam yang dihasilkan oleh generasi ulama secara turuntemurun (seperti: para hakim, teolog, mufasir, moralis, kaum sufi, dan tradisionalis, yang telah membangun korpus-korpus majemuk dalam tradisi muslim dengan tiga jalur utamanya; golongan Sunni, Syi'ah dan Khawarij) (Arkoun, 1988: 64).

Dalam perspektif Arkoun sendiri, "Wahyu dalam al-Qur'an" pertamatama adalah hasil dari pembuktian linguistik; struktur sintaksis, semantik, dan semiotika diskursus al-Qur'an, yang menyediakan satu ruang komunikasi secara total diartikulasikan untuk mengutarakan pemikiran (gagasan) dan isi wahyu tersebut. Untuk menjelaskannya, Arkoun mengambil contoh pada QS. al-`Alaq. Dalam membaca surah ini, Arkoun menyatakan bahwa Allah 'kelihatan-nya' (appears) sebagai pelaku sentral, mengatur tatabahasa (grammatically) dan semantik seluruh wacana. Tetapi terdapat pula, dua pelaku utama atau pendukung lainnya, seorang

Ulul Albab, Vol. 8 No. 2, 2007 
Nabi yang menerima firman (baca: perintah), dan manusia sebagai objek dan alamat terakhir dari semua tindakan yang diungkapkan oleh kata kerja yang banyak itu.

Dengan membaca surat al-'Alaq di atas, problem linguistik tak dapat dihindarkan lagi ketika memahami "wahyu dalam al-Qur'an". Untuk itu, kata Arkoun, kita harus mempertimbangkan tiga hal utama dalam wacana al-Qur'an (wahyu); organisasi metaforis, struktur semiotik, dan intertekstualitas. Sampai saat ini, lanjut Arkoun, hal yang pertama cukup sulit untuk dijelaskan secara luas, kecualijika pendefinisian terhadap metonomia dan metafora secara tradisional telah 'dibebaskan', tidak dibatasi hanya sebagai alat retorika sederhana yang dipakai untuk memperindah gaya. Terlebih lagi, kata-kata yang mengantarkan pada interpretasi antropomorfis agak diterima dalam arti yang selayaknya, seperti "Allah mengajar dengan pena", "Allah Maha Mendengar" dst.. Seperti dicontohkan kesulitannya itu, menurut Arkoun, karena hanya menunjukkan bagaimana wacana alQur'an telah dipergunakan sebagaipretext (dalih), bukan sebuah text. Maka dari itulah dengan terpaksa, persoalan tentang metafora dalam wacana alQur'an, menurut Arkoun, sembari dengan ketiadaan teori yang ada dan lengkap, untuk sementara ditinggalkan (Arkoun, 1988: 43).

Sedangkan struktur semiotik wacana al-Qur'an, seluruh wacananya didominasi oleh teknik persuasi, yang dalam istilah semiotik, kata Arkoun, kita dapat mengatakan bahwa tiap unit tekstual menyajikan tiga langkah:

1) Allah mengumumkan hukuman atau menyampaikan pesan.

2) Beberapa orang yang disapa Allah mendengarkan pesannya; beberapa orang mendengarnya dan menolak mempercayai; beberapa lagi menerima pesan sebagai pengetahuan, tetapi menolak menaatinya dalam ibadah dan dalam sehari-hari; dan hanya sedikit saja yang sepenuhnya mempercayai (beriman) dan menerima pesannya.

3) Pada hari Kiamat tiba, bagi yang beriman, dikaruniai keselamatan, sementara bagi pendurhaka, disiksa dan ditolak oleh Allah.

Ulul Albab, Vol. 8 No. 2, 2007 
Struktur dramatis tersebut, seperti yang disebut Arkoun, memiliki dasar sosial, politik, dan budayanya di Makah dan Madinah, dimana beberapa kabilah mengikuti Nabi dan sebagian kabilah lain berperang melawannya. Di sini, wacana al-Qur'an penting, karena memberikan struktur semiotik paradigmatis pada masalah-masalah yang khas bagi masyarakat Hijaz, awal abad VII. Jika dibuatkan diagram, struktur paradigmatis tersebut sebagai berikut:

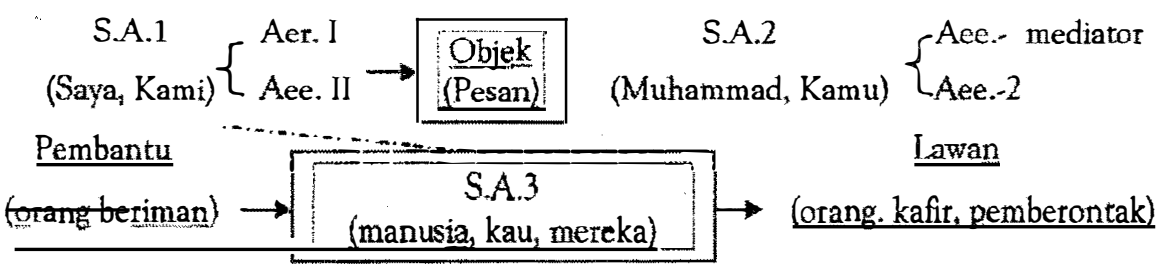

\section{Keterangan:}

\begin{tabular}{|c|c|c|}
\hline S.A. & $=$ Subjek Actant & $=$ Subyek Pelaku \\
\hline Aer. & $=$ Addresser & $=$ Pengirim (yang menyapa) \\
\hline Aee. & $=$ Addresse & $=$ Penerima (yang disapa) \\
\hline
\end{tabular}

Arkoun, sengaja menggunakan terminologi yang sangat teknis dan abstrak untuk semiotik tersebut, di samping agar hanya mempertimbangkan fungsi-fungsi dan tokoh utama (protagonis) yang mendatangkan hasil melalui pertentangan dramais, juga untuk menghindari sama sekali konotasi kaya yang dimiliki kosakata kita selama berabad-abad. Dan ini pula, syarat metodologis untuk menunjukkan keberadaan Allah dan wahyu dalam suatu lingkup istimewa wacana al-Qur'an, yang serupa dalam lingkup wacana Taurat, yakni memiliki struktur semiotik sama.

Adapun untuk analisis tentang intertekstualitas dalam wacana alQur'an, bisa dicontohkan secara luas pada QS al-Kahf. Surat urutan ke-18 ini, menurut Arkoun di dalamnya terdapat tiga narasi (kisah), yaitu orangorang di gua (ashab al-kahf?), legenda Gilgamesh (Nabi Khidir), dan novel 
Iskandar Agung (Zulqarnain). Ketiganya ini, merupakan suatu kisah yang mewakili imajinasi kultural terkuno yang lazim di Timur Tengah, dikombinasikan dalam satu surat yang sama untuk menguatkan dan mengilustrasikan tentang transmisi pesan. Darisetiap kisah itu -lanjut Arkounterdapat satu tokoh utamanya (protagonis) sebagai penerima pesan, yang selanjutnya menggunakan pengetahuannya untuk mengubah signifikansi akhir atas keberadaan manusia, dalam hubungannya dengan Tuhan dan ajaran-ajaran-Nya.

Jadi problem linguistik itu, saat ini adalah sesuatu yang penting untuk memasuki al-Qur'an secara ilmiah. Seperti disebutkan Arkoun di atas, tentang 'pembacaan' kembali pada al-Qur'an.

\section{b. Wahyu dalam Pikiran Islam: Sebuah Fakta Budaya}

Demi menjaga autentisitas sebuah kitab suci, wahyu-ilahi yang ditulis para Sahabat Nabi — baik individual, kelompok — ataupun suatu tim yang berwenang secara resmi dari pihak Nabi/Khulafa' ar-Rasyidun dikumpulkan dan diseleksi untuk menjadi sebuah kitab. Proyek-spektakuler-monumental dalam menghimpun atau mengumpulkan wahyu tersebut telah dimulai sejak zaman Khulafa' ar-Rasyidun pertama, Abu Bakar as-Siddiq, namun secara resmi sebagai wahyu yang telah sempurna dan menjadi Mushaf al-Qur'an dinyatakan pada zaman Usman ibn Affan, Khalifah ketiga dari Khulafa' arRasyidun (Mahrus, 1998). Mulai saat itulah mushaf al-Qur'an telah dinyatakan tertutup secara resmi dan secara utuh diterima pula oleh umat Islam saat itu. Bahkan hingga kini, al-Qur'an (mushaf 'Usmani/al-mushaf) itulah yang dijadikan sebagai pegangan, standar-keasliannya bagi umat Islam, seantero dunia, yang dalam istilah Arkoun disebut korpus resmi tertutup (official closed corpus).

Sebagai fakta budaya, kata Arkoun, mushaf mempunyai tiga implikasi dasar:

1) Wacana al-Qur'an, mula-mula diucapkan dan dipakai sebagai wacana lisan, lalu menjadi sebuah teks. Transformasi ini akan menimbulkan

Ulul Albab, Vol. 8 No. 2, 2007 
sejumlah perubahan radikal, yang harus dipertimbangkan secara linguistik dan semiotik.

2) Sifat suci teks ini akan diperluas mencakup buku (kitab)-nya sebagai wadah materi dan sarana bagi wahyu.

3) Kitab (buku) tersebut sebagai instrumen budaya akan menjadi dasar bagi perubahan fundamental lain dalam masyarakat Kitab, yakni meningkatnya peran, dan akhirnya dominasi budaya terpelajar memakai tulisan (written-leamed culture) atas budaya rakyat memakai lisan (oral-folk culture), ini cukup berkait dengan negara. Kemudian, ini juga akan mendukung munculnya kelompok sosial yang disebut ulama, baik yang disebut mufasir Al-Qur'an maupun ahli fiqh dan kalam secara ortodoks.

Menurut kekuatan dan kebutuhan baru dalam bidang budaya, politik, serta sosial -tegas Arkoun — akan muncul banyak korpus sekunder dalam pelbagai proses historis, di bawah dukungan fenomena Kitab-buku yang harus dibedakan dari fenomena wahyu. Korpus sekunder ini disebut Arkoun sebagai korpus tertafsir (interpreted corpuses/mudawwanah nassiyyah tafsiriyyah). Diantara contoh yang termasuk kategori itu, antara lain; Muwatta (Malik Ibn Anas), Kitab al-Umm (Syafi'i), Musnad Ibn Hanbal (Hambali), Sahihain (Bukhari-Muslim), kitab Kafi (al-Kulaini), serta kitab-kitab Tafsir al-Qur'an, baik kategori klasik ataupun modern, yang berbahasa Arab ataupun yang non-Arab ('ajam). Jadi, korpus tertafsir itu tidak hanya merujuk pada berbagai penjelasan tentang Al-Qur'an (tafsir), tapi juga kumpulan sunnah, karena termasuk perluasan budaya dari gejala Kitabbuku, yang menghubungkan diri dengan fenomena wahyu.

Seperti diketahui, bahwa cukup banyak buku yang dihasilkan sebagai kegiatan budaya dan intelektual untuk menanggapi tuntutan negara (resmi/ tidak) dan, atau masyarakat sipil. Hal demikian itu, tidak terpisahkan dari perwujudan kitab yang kolektif dan umum sebagai kitab Syurgawi. Dengan kata lain, menurut Arkoun, aktifitas nalar yang rasionalis dan logosentris

Ulul Albab, Vol. 8 No. 2, 2007 
yang termaktub dalam semua jenis kitab, sedikit banyak dipengaruhi, dibimbing, dan diilhami ak fitasimaginaere yang mewakili gambaran mental dari Kitab-wahyu.

Seterusnya, seluruh komunitas (ummah) mempunyai kepentingan dengan fenomena Kitab-buku. Setiap anggota komunitas berhak memakai (interpretasi) teks yang dipilih dari potongan ayat Mushaf 'Usmani atau Sunnah/Hadis, sesuai dengan situasi-kondisi yang ada. Komunitas yang melakukan interpretasi itu adalah subyek-pelaku dari semua sejarah bumi (subject-actant of the whole terrestrial history) yang diwakili, diinterpretasikan, dan digunakan sebagai suatu tahapan yang amat sukar dalam menyiapkan penyelamatan, menurut sejarah penyelamatan yang disampaikan Allah sebagai bagian edukatif wahyu.

Terdapat pendekatan lain untuk menjelaskan fungsi-fungsi wahyu dalam pikiran Islam, lanjut Arkoun dalam paparannya, yakni teks yang diwahyukan yang dijaga dalam Mushaf digunakan secara umum dan teratur sebagai ruang tak terbatas untuk proyeksi mental dari semua tipe ideal kesempurnaan eksistensi yang ingin diraih olehsetiap orang beriman. Konsep proyeksi mental ini, membantu menunjukkan bagaimana teks Qur'ani dipakai sebagai pretext, bukan sebagai text menurut definisi sejarah dan linguistik modern, saat ini. Berarti, simpul Arkoun, teks asli al-Qur'an telah ditulis ulang, direproduksi dalam perkembangan sejarah suatu komunitas tertentu (atau, tegas Arkoun, kita harus sebut masing-masing masyarakat dimana fenomena Kitab-buku diberlakukan).

Dengan demikian, wahyu dinyatakan sebagai realitas ilahiah yang substansial dan tidak dapat diubah, namun juga, pada saat yang bersamaan, telah dimanipulasi menurut kebutuhan-kebutuhan konkret, mendesak dari para pelaku-pelaku sosial. Dicontohkan Arkoun Ilmu-ilmu Usul Fiq̨h. Ilmu tersebut merupakan strategi intelektual dan 'ilmiah' yang dipakai untuk memperluas kumpulan teks wahyu dengan menambahkan sunnah Nabi (Hadis) pada al-Qur'an, dan juga tradisi imami bagi kaum Syi'ah. Mereka, pakar hukum memaparkannya dalam gramatika, semantik, dan retorika bahasa Arab, juga pengetahuannya yang luas mengenai ilmu-ilmu lain,

Ulul Albab, Vol. 8 No. 2, 2007 
semisal Asbab an-Nuzul, Nasikh-Mansukh, untuk menunjukkan bagaimana nalar manusia merupakan hamba "Firman Allah" dan untuk memperdalam keyakinan bahwa wahyu diberlakukan dalam tatanan sosial, politik, etis, dst. Padahal, kenyataannya dengan konstruksi ini kita mempunyai gambaran sikap nalar umum dalam masyarakat Kitab, yakni suatu nalar yang menghasilkan suatu rasionalitas imajiner, dengan jaminan bahwa ini merupakan nalar yang sangat terpadu, logis, dan ilmiah. Oleh karenanya, menurut Arkoun, suatu dekonstruksi kritis gagasan dan tipe rasionalitas yang mendasari "ilmu" usul fiqh ini, merupakan salah satu langkah penting untuk secara modern menilai kembali wahyu sebagai gejala budaya dan sejarah yang komplek.

\section{Wahyu dan Masyarakat (Ber-)Kitab: "Bahasa-Sejarah-Pemikiran"}

Selain daripada itu, Arkoun juga melihat bahwa dalam al-Qur'an terdapat beberapa umat sebelum (umat) Muhammadyang pernah menerima wahyu, yang disebut dalam istilah ahl al-kitab. "Orang-orang Kitab" yang telah digunakan al-Qur'anitu lebih sempit, daripada pengertian "Masyarakat Kitab", yang dikatakan Arkoun lebih luas dan kompleks (Arkoun, 1988: 86).

Bagaimanakah Arkoun melihat keterkaitannya antara wahyu dan masyarakat ber-Kitab? dan siapa sebenarnya masyarakat Kitab itu? Melalui jaringan circular antara bahasa, sejarah, dan pemikiran, dua pertanyaan tersebut akan terungkap pada paparan berikut ini.

Arkoun memaparkan, dalam Mushafal-Qur'an disebutkan bahwa ahl al-kitab (ahli Kitab) adalah orang-orang Yahudi dan Nasrani (Kristen) yang harus dihadapi Nabi Muhammad saw. di Makah dan Madinah. Mereka adalah umat pemilik wahyu yang lebih awal dan orang-orang beriman, yang juga dikasihi Allah sebagaimana orang-orang Muslim, yang telah menerima wahyu 'barunya'. Namun disebutkan juga, bahwa sebagian mereka menentang Muhammad sebagai seorang Nabi, dan menolak untuk menerima al-Qur'an sebagai wahyu, firman Allah yang terakhir.

Ulul Albab, Vol. 8 No. 2, 2007 
Berkaitan dengan mereka yang seperti itu, dalam al-Qur'an juga dijelaskan, lanjut Arkoun, dengan menyebutkan: (1) Mereka adalah sasaran Kitab, meskipun mereka menolak bahwa hal itu dari 'Kitab'; (2) Kitab diidentifikasi sebagai al-Qur'an, sebelum menjadi Mushaf, yang pada akhimya juga disatulen dengan 'Kitab'; (3) Orang-orang Islam diintegrasikan ke dalam komunitas spiritual, yang disebut ahl al-kitab sesuai dengan definisi baru yang diberikan al-Qur'an. Sehingga, orang-orang Islam menjadi wakil sesungguhnya dari ahl al-kitab dan Islam sebagai agama yang sebenamya, satu-satunya agama kebenaran; (4) Pada QS at-Taubah: 29, terdapat pemisahan yang tegas antara orang Islam dan ahl cl-kitab, yang berarti Yahudi dan Kristen, yakni yang telah membengkokkan ( $t a h r i f)$ kitab Injil dan harus membayar pajak; (5) Terdapat pembatasan lebih ketat yang ditetapkan antara ahl al-kitab, yakni mereka yang tercerahkan dengan 'pengetahuan ('ilm)' yang terdapat dalam Kitab, dan orang-orang 'pagan' (uanmiynun, jahiliyyun) yang sama sekali tidak bersentuhan dengan 'ilm.

Pada poin terakhir tersebut, sepertinya Arkoun akan menawarkan sebuah 'pembacaan' baru atas ahl al-kitab, selarasdengan konsep "Masyarakat Kitab", the concept of "The Societies of The Book" yang dimungkinkan untuk memikirkan ulang konsep lama mengenai ahl al-kitab, tanpa bergantung pada definisi polemis dan "teologis" yang hingga kini masih berlaku. "Masyarakat" yang dimaksud, merujuk pada konsep semua metodologi dan problematika yang dipakai dalam ilmu-ilmu sosial, politik, dan humaniora saat ini. Adapun "Kimb", dalam hal iniperlu dikaji ulang berkaitan fenomena Kitab-buku, yakni dengan memberlakukan pendekatan antropologi-kritis terhadap semua jenis organisasi kemasyarakatan (Arkoun, 1998: 85).

Dengan demikian dari paparan terbatas di atas, dapat diambil suatu kesimpulan sementara, bahwa ahl al-kitab dalam pandangan Arkoun, tidak terbatas hanya pada umat Yahudi, Kristen, Islam saja, tapi juga segenap masyarakat yang mempunyai Kitab, yang diyakini berkarakteristik ilahiyah atas kitab tersebut. Seperti dikatakan Arkoun secara implisit, dalam tulisannya "Agama, Masyarakat, Sejarah", bahwa masyarakat-masyarakat

Ulul Albab, Vol. 8 No. 2, 2007 
Kitab adalah mereka yang tunduk dan patuh kepada otoritas iman kitabkitab suci.

Sebagaimana diungkapkan Arkoun tentang ahl al-kitab dalam wahyu al-Qur'an tersebut, semakin terlihat kaitannya wahyu dan masyarakat berKitab dalam hubungannya dengan bahasa, sejarah, dan pemikiran. Sebagai wahyu yang terakhir, al-Qur'an memperhatikan atau mempedulikan mereka, dan Muhammad, dengan sendirinya umat Islam saat ini, mempunyai tugas dan fungsi sebagaimana termaktub dalam al-Qur'an tersebut. Bahasa, sebagai alat berpikir sekaligus menjadi kumpulan ucapan dan tulisan di masyarakat, baik di masa lampau maupun masa kini (sejarah), telah cukup berkaitan dengan pemikiran, sesuai dengan pola-pola kebudayaan yang telah disepakati.

\section{Dialektika "Wahyu-Kebenaran-Sejarah"}

Dengan melihat, pengalihan wacana al-Qur'an yang bermula atas tradisi lisan (penyampaian) menjadi teks al-Qur'an (korpus resmi tertutup/ Mushaf) sebagai tradisi tulis yang telah disepakati oleh semua orang Islam, merupakan sebuah proses dari produk sejarah, pemikiran, dan bahasa, pada zamannya. Jadi, hubungan antara ketiganya itu bukan hubungan linear tapi circular, yang saling melengkapi.

Dari peralihan tersebut, tidak menutup kemungkinan akan adanya pemikiran yang memposisikan "teks" menjadi "preteks", dan hal ini telah terjadi secara besar-besaran pada sejarah kehidupan umat Islam.

Dipaparkan Arkoun, bahwa al-Qur'an —setelah menjadi teks- tidak dapat diperlakukan sebagai sebuah dokumen susastra dan historis, kecuali sebagai tambahan. Itu artinya, kita mesti membalikkanmetode yang dihormati oleh kaum fundamentalis kuno dan para penafsir modern, bahwa ayat-ayat tidak akan mendapatkan maknanya dari asbab an-nuzul, tetapi justru dapat memberikan kepada sejarawan tanda-tanda mengenai keadaan kebudayaan dan masyarakat di jazirah Arab pada awal abad VII M. Sebab, lanjut Arkoun, mengaitkan ayat-ayat dengan lingkungan keadaan wahyu, berarti 
mengangkat sebagaimana dilakukan orang, ide positivis mengenai wahyu opartunis, dari seorang Rasul yang meminta pertolongan kepada Tuhan saat-saat yang sesuai. Itu artinya, juga menjumudkan dalam kandungan sebuah teks yang maksud utamanya dan hasil efektifnya adalah mengaktifkan sejarah (Arkoun, 1988: 72). Seperti, kasus interpretasinya para sufi pada alQur'an dengan menggunakan sastra mistiknya. Yakni, memberikan interpretasinya secara batiniah (esoterik), sebagai lawannya dari yang dhahiriah (harfiah). Salah satu contoh, khayalan kreatifnya Ibn Arabi, yang menurut Arkoun menimbulkan dua masalah besar tentang wahyu; Pertama, bagaimana kita dapat menjelaskan kekuatan sugestif yang membangkitkan semangat melekat dalam wacana al-Qur'an; Kedua, dalam konteks budaya sekuler kita, bagaimana dapat kita jelaskan hilangnya, irelevansinya, dan disintegrasi wacana al-Qur'an, sekaligus lenyapnya rasa hormat.

Dengan melihat kasus sufi tersebut, dalam wacana agama dan irrelevansinya pada konteks modern, bagi sejarah pemikiran agama menimbulkan suatu masalah yang sukar mengenai sejarahnya, yakni wahyu itu sendiri. Sedangkan, dalam doktrin Islam secara keseluruhan kebenaran wahyu telah diakui keabsahannya sejak mulai diturunkan, sampai dengan terbentuknya Mushaf resmi.

Maka, sesungguhnya hubungan dialektis ini masih tetap menuntut pengkajian lebih lanjut. Seperti dikatakan Arkoun, bahwa yang kita dapat baca dari karya kaum Muslim hanyalah pernyataan yang diulang-ulang mengenai kebenaran, keabadian, dan kesempurnaan dari Risalah yang diterima dan disampaikan oleh Nabi Muhammad.

\section{Kesimpulan}

Dengan ulasan singkat di atas, melalui latar pikir Arkoun sebagai orang Arab asal Berber, Aljaza'ir dan bersentuhan dengan filsafat kontemporer di Eropa, nampaknya wahyu ilahi (al-Qur'an) senantiasa hidup di tengah manusia sampai kapanpun. Hanya saja, dalam hemat penulis, setelah Arkoun mengungkap wahyu dari berbagai perspektif di atas, teo-antropologiwahyu sebagai poros ide tentang wahyunya belum tuntas terungkap dalam

Ulul Albab, Vol. 8 No. 2, 2007 
analisisnya. Barangkali hal itulah yang menjadi tanggung jawab para ilmuwan muslim, pemikir studi al-Qur'an pasca Arkoun untuk merumuskan teo-antropologi-wahyu.

Jendela pemikiran tentang wahyu telah terbuka melalui Arkoun, pintu Ulumul Qur'an semestinya juga terbuka, lantas siapa yang masuk dalam dunia wahyu yang disentuh Arkoun di atas? Masihkah studi ulumul qur'an hanya "terjebak" pada ulama klasik semata? Mudah-mudahan bahasan singkat ini mampu mengetuk bilik-bilik intelektual pasca Arkoun.

\section{DAFTAR PUSTAKA}

Abdalla, Ulil Abshar. 1994. Kritik Atas Nalar Islam: Membaca PikiranPikiran M. Arkoun. Bangkit, VII/III,.

'Ajil, Louis (ed.). 1984. Al-Munjid fi al-A'lam, Beirut: Dar al-Mashreq Publishers.

Arkoun. 1992. Al-Fikr al-Islam: an-Naqd wa Ijtihad, terj. Hasyim Salih, Beirut: Dar al-Saqi.

1993. Gagasan tentang Wahyu: Dari ahl Kitab hingga Masyarakat Kitab dalam Lilian D.T., Studi Islam di Perancis, Jakarta: INIS.

- 1984. Islam et development dans le Maghreb independent, dalam Arkoun, Pour une critique de la raison islamique, Paris: Maisonneuve et Larose.

. 1996. Kritik Konsep 'Reformasi Islam, dalam Dekonstruksi Syari'ah (II) Kritik Konsep Penjelajahan Lain. penterj. Farid Wajidi, Yogyakarta: LKiS.

1990. Menuju Pendekatan Baru Islam. penterj. Hamid Basyaib sekaligus hasil wawancaranya dengan Arkoun, Ulumul Qur'an, VII/ II .

. 1988. The Notion of Revelation: From Ahl al-Kitab to the Societes of the book. Die Welt des Islams, Paris: 1988/XXVIII, pp. 6465.

1987. Al-Fikr al-Islami, Qira'at 'Ilmiyyaat. penterj. Hasyim Salih, Beirut: Markaz al-Inma' al-Qaumi. 
1986. Al-Islam: Asalah wa Mumarasah. penterj. Khalil Ahmad, ([t.n.]: [t.k.], INIS.

1997. Berbagai Pembacaan al-Qur'an. terj. Machasin, Jakarta: 1997. Islam Kemarin dan Hari Esok. terj. Ahsin Muhammad, Bandung: Pustaka.

1996. Rethinking Islam. terj. Yudian dan Lathiful Khuluq, Yogyakarta: Pustaka Pelajar.

Badawi, A. Zaki. 1993. A Dictionary of The Soscial Science: English, French, Arabic. Beirut: Libraire Du Liban.

Echols, John M., dan Hassan Shadily. 1992.Kamus Inggris Indonesia. Jakarta: Gramedia.

Mahrus. 1998. Mohammed Arkoun Tentang Wahyu (Studi Perbandingan dengant Abu Ja'far at-Tabari dan Abdullah Yusuf Ali). Penelitian, Tidak diterbitkan, IAIN Jogjakarta.

Meuleman, J. H. 1994. Pengantar dalam Arkoun, Nalar Islami dan Nalar Modern: Berbagai Tantangan dan Jalan Baru. terj. Rahayu S. Hidayat, Jakarta: INIS.

Meuleman, J. H. 1996. Tradisi, Kemodeman dan Metamodemisme. Yogyakarta: LKiS.

Sa'ad, Suadi. 1995. Islam Menghadapi Tantangan Kemodernan: Pandangan Mohammed Arkoun. Thesis, tidak diterbitkan IAIN Syarif Hidayatullah Jakarta.

Salim, Peter, dan Yenny Salim. 1991. Kamus Bahasa Indonesia-Kontemporex: Jakarta: Modern English Press,.

Tamara, M Nasir. 1989. Mohammed Arkoun dan Islamologi Terapan dalam Ulumul Qur'an No. 03, Vol. 1.

Ulul Albab, Vol. 8 No. 2, 2007 